\title{
Do EsvaZiamento da Fé À Fé do AUTO-ESvaZiamento
}

\author{
FROM THE EMPTYNG OF FAITH TO FAITH OF SELF-EMPTYING
}

\author{
DEL VACIAMIENTO DE LA FE A LA FE DEL AUto-VACIAMIENTO
}

\author{
Aíla Luzia Pinheiro de Andrade* \\ Solange Maria do Carmo**
}

\begin{abstract}
RESUMO
Partindo da realidade atual marcada por uma ênfase em elementos periféricos de uma religiosidade alienante e um consequente esvaziamento da fé cristã em seu núcleo essencial, o artigo tem como objetivo principal proporcionar uma reflexão acerca da necessária volta à teologia paulina sobre o esvaziamento de Cristo como fonte e paradigma para a fé cristã. Para isso, serão percorridos os seguintes passos: considerações iniciais sobre a Carta aos Filipenses; estudo do conceito de kénosis como fio condutor da Carta, a kénosis de Cristo como expressão máxima de sua fidelidade a Deus; a kénosis de Paulo como atitude exemplar para todos os cristãos, a kénosis invertida dos judaizantes como impedimento para autêntica fé cristã. Conclui-se que na fé do auto-esvaziamento (kénosis) residem a riqueza e a glória do cristianismo, e não nos excessos religiosos.
\end{abstract}

Palavras-chave: Fé. Auto-esvaziamento. Kénosis. Filipenses. Vivência cristã.

\begin{abstract}
From the current reality marked by an emphasis on peripheral elements of an alienating religiosity and consequently the emptying of the Christian faith in its essential core, the main objective of the article is to reflect a necessary return to the Pauline theology of the emptying of Christ as the source and paradigm of the Christian faith. Therefore, the following steps will be taken: a general approach to the Letter to the Philippians; study of the concept of kenosis as a common thread of the Letter; the kenosis of Christ as the highest expression of his fidelity to God; the kenosis of Paul as an exemplary attitude for all Christians and the reverse of the kenosis in the actions of the Judaizers as an impediment to the authentic Christian faith. The study concludes that the wealth and glory of Christianity are in the self-emptying (kenosis) and not in the external expressions of religion.
\end{abstract}

Keywords: Faith. Self-emptying. Kenosis. Philippians. Christian experience.

\section{RESUMEN}

Desde la realidad actual marcada por un énfasis en elementos periféricos de una religiosidad alienante y en consecuencia el vaciamiento de la fe cristiana en su cerne esencial, el objetivo

\footnotetext{
* Doutora em Teologia Bíblica pela Faculdade Jesuíta de Filosofia e Teologia. Integrante do Programa de PósGraduação em Teologia da Universidade Católica de Pernambuco. Brasil. ORCID: 00oo-0002-2339-1134. Email: aylanj@gmail.com.

** Doutora em Teologia da Práxis Cristã pela Faculdade Jesuíta de Filosofia e Teologia. Mestre em Teologia Bíblica pela Faculdade Jesuíta de Filosofia e Teologia. Docente da Pontifícia Universidade Católica de Minas Gerais e do Instituto Santo Tomás de Aquino. Brasil. ORCID: 0000-0002-7993-2673. Email:carmosolange@gmail.com.
} 
principal del artículo es proporcionar una reflexión sobre un necesario retorno a la teología paulina del vaciamiento de Cristo como fuente y paradigma de la fe cristiana. Por tanto, se darán los siguientes pasos: planteamiento general acerca de la Carta a los Filipenses; estudio del concepto de kénosis como hilo conductor de la Carta; la kénosis de Cristo como máxima expresión de su fidelidad a Dios; la kénosis de Pablo como actitud ejemplar para todos los cristianos y el reverso de la kénosis en las acciones de los judaizantes como impedimento para la auténtica fe cristiana. El estudio concluye que la riqueza y la gloria del cristianismo están en el autovaciamiento (kénosis) y no en las expresiones externas de la religión.

Palabras Clave: Fe. Auto-vaciamiento. Kénosis. Filipenses. Experiencia cristiana.

\section{INTRODUÇÃO}

Muito se tem falado ultimamente do excesso nas vestes litúrgicas, no uso do incenso e no exagero nos ritos litúrgicos. Mas não é só a liturgia que está folclorizada e com sua leveza comprometida. A piedade cristã sofre inflação; ganhou proporções gigantescas e ocupou o espaço do evangelho. A boa-nova de Jesus Cristo ficou comprometida quando as práticas religiosas se tornaram mais importantes que a radicalidade do amor exigido pelo evangelho (Jo 15, 12). Não é à toa que alguns falam de cristianismo sem religião, ${ }^{1}$ pois o esvaziamento da fé cristã de seu significado mais profundo leva a uma rejeição das configurações que a fé, por meio da religião, adquiriu na história. Em muitos casos, a religião dá mostras de atrapalhar a difusão da fé e subtrai a força da Palavra que faz viver (GRECH, 2018).

Rezas, devoções, novenas, catecismos. Noventa salve-rainhas, nove comunhões nas sextas-feiras, dez Creio em Deus Pai, a oração de São Miguel e a medalha de São Bento, o terço dos anjos, o rosário da Virgem, o Cerco de Jericó, comungar ajoelhado, confessar-se com exagerada frequência, colocar um véu sobre a cabeça, uma corrente nos braços em devoção à Virgem, participar de peregrinações a lugares santos, guardar a preciosidade de uma relíquia, rezar pelas almas do purgatório, obter uma indulgência plenária. Estudar o Catecismo da Igreja, ensinar aos jovens o Youcat, saber o que disse o papa Pio X, conhecer o rito de Pio V, apegar-se a uma afirmação de João Paulo II ou a uma declaração de Bento XVI; a lista é infinita. Arquitetada por uma armada do papa, ${ }^{2}$ uma inflação religiosa que compromete a fé cristã pode ser vista a olhos nus. Codina (2012) formula uma questão que faz pensar:

\footnotetext{
${ }^{1}$ Como é o caso dos autores Mario Grech (2018), que trata da concepção de cristianismo sem religião e Vicente Ferreira (2015), que se vale do termo cristianismos não religiosos (cristianismo não religioso).

${ }^{2}$ Expressão usada por Urquhart (2002), e, que, constitui o título de sua famosa obra A armada do papa: os segredos e o poder das novas seitas da Igreja Católica.
} 
Não vivemos uma inflação de doutrinas, palavras, magistério, catecismo, aulas de religião, cursos de formação, homilias, transmissão de conceitos e tradições... em comparação com um déficit de experiência espiritual, de interioridade, de iniciação, de silêncio contemplativo e de mistagogia? (CODINA, 2012, p. 76).

O fragmento supracitado pontua o que parece ser o despertar da bela adormecida que o Vaticano II fizera adormecer. Muita devoção e excesso de religiosidade podem comprometer a interioridade da fé cristã, dando a entender que é na exterioridade das práticas devocionais e, nas afirmações dogmáticas solidificadas no senso comum que, se encontra a genuinidade cristã. Longe de querer desprezar a piedade popular, o objetivo deste artigo é proporcionar uma reflexão acerca da necessária volta às fontes cristãs, que passa pelo auto-esvaziamento. Como afirmou Codina (2012), “[...] não se pode ter acesso à fé cristã e à Igreja sem uma experiência interior.” (CODINA, 2012, p. 80). É no interior dos corações que a palavra de Deus foi inscrita e não na exterioridade dos pergaminhos. É a linguagem da consciência que é propriamente divina e não o latim dos documentos pontifícios ${ }^{3}$. Apesar de ser reconhecida a necessidade da tematização da fé por meio da formulação de dogmas, preceitos e leis e de ser assumido o valor da religiosidade, que se traduz em celebrações, ritos, sinais e gestos, a fé cristã não se circunscreve em nenhuma dessas modalidades, mas no esvaziamento de si mesmo, que só o amor é capaz de suscitar, a exemplo de Jesus de Nazaré. Impregnado de exterioridades que o sufocam, o cristianismo carece de um sério programa de desintoxicação.

Na tentativa de deflacionar o cristianismo, o Papa Francisco tem insistido na volta ao evangelho. Para ele, o que deve sobressair no anúncio do Evangelho é "[...] a beleza do amor salvífico de Deus manifestado em Jesus Cristo morto e ressuscitado.” (FRANCISCO, 2015, p. 32). Tudo o mais corre o risco de se tornar um castelo de cartas, inclusive a moral cristã. Se isso acontece, “[...] não estaremos propriamente a anunciar o Evangelho, mas algumas acentuações doutrinais ou morais, que derivam de certas opções ideológicas. A mensagem correrá o risco de perder o seu frescor e já não ter 'o perfume do Evangelho.”' (FRANCISCO, 2015, p. 35).

Apesar dos insistentes apelos do Papa Francisco, grande parte dos cristãos, e até do episcopado, como afirma o historiador Sergio Ricardo Coutinho em artigo publicado no site do Instituto Humanitas Unisinos, 4 parece não ter aderido ao projeto de reforma da Igreja

\footnotetext{
${ }_{3}^{3}$ Segundo os evangelistas, a oração do Pai-nosso, ensinada por Jesus aos seus discípulos, é dada no idioma do povo, não no hebraico, língua obrigatória para as orações dos judeus naquela época. Pode-se inferir daí a rejeição por parte da comunidade cristã (e por que não, de Jesus) de um idioma sagrado, como defendiam as lideranças religiosas do judaísmo daquele tempo, atitude na qual a igreja incorreu posteriormente.

$4 \mathrm{O}$ artigo supramencionado é intitulado CNBB (1968) x CNBB (2018): a 50 anos de distância o que esperar? (COUTINHO, 2018).
} 
conforme intenta o Papa. Esses nostálgicos cristãos se mostram impactados com o atual pontificado, mas ainda esperam viver os anos gloriosos de João Paulo II ou de Bento XVI, quiçá de Pio V. Não se opõem frontalmente ao Papa Francisco; isso seria próprio de cismáticos - coisa que eles não são - mas também não deixam a Igreja caminhar; estão sempre puxando a vida cristã para trás, numa tentativa inglória de resguardar a doutrina, os costumes e a moral, cristalizados num formato que não existe mais.

No meio católico, movimentos neoconservadores respingam-se de borrifos fundamentalistas. Atêm-se à rigidez da lei, à literalidade do texto religioso ou canônico, à submissão inconteste às autoridades, com culto aos líderes. A insegurança provocada pela perda de referências básicas de vida, de valores, por obra da modernidade e da pósmodernidade, aninha-se bem em posições fundamentalistas. (LIBANIO, 2009, p. 12).

Trata-se de pessoas que se afeiçoaram de tal modo a adereços e maquiagens da fé que estes foram considerados sacrossantos e eternos, mais importantes que a própria fé no Cristo. Estão tão acostumados aos enfeites do cristianismo que, tirando os apetrechos, sentem-se inseguros e perdem sua identidade. São como a Elke Maravilha, que, em entrevista, admitiu estar tão ajustada a seu personagem, que não sabia mais quem era quando se encontrava desvestida de sua fantasia. Retirada a aura de absoluto, de seus costumes piedosos e suas formulações dogmáticas, encontram-se desnudos como Adão e Eva diante do Criador. O excesso de quinquilharias religiosas atua como as tangas de figueira do relato do Gênesis $(3,7)$ : servem para cobrir a vergonha, ou no caso, a insegurança dos crentes, pois conservam certo conforto espiritual de tempos idos.

Para esses cristãos, qualquer pessoa que se empenha em despir a religião cristã de seus excessos rituais e dogmáticos - falemos especialmente da religião católica - é acusada de esvaziamento da fé. É o que tem acontecido em sala de aula nos cursos de Teologia. Alunos de fé ingênua e piedosa revoltam-se quando, nas aulas de Sagrada Escritura, veem questionados os fundamentos do misticismo religioso. Torcem o nariz diante dos resultados da pesquisa exegética. Fazem caretas quando desafiados a ler teólogos e biblistas que não se encontram no rol de sua ortodoxia. Acusam seus professores de esvaziar a fé. Constantemente, quando refletem sobre os excessos da religião e suas consequências perniciosas, teólogos e teólogas são ofendidos em público, chamados de hereges e considerados um perigo para a Igreja. São taxados de comunistas e lhes é direcionado o famoso jargão Vai pra Cuba.

Esses que se consideram supercatólicos cultivam a ilusão de uma fé intocada e imaculada diante das ameaças da modernidade. Desconhecem o trabalho da teologia, que é 
manter o frescor da fé que garante sua saúde, evitando que ela se transforme em pão bolorento. Entendem a dúvida e a suspeita não como possibilidade de uma fé lúcida, mas como uma ameaça. São verdadeiros cães de guarda, sempre a postos nos umbrais do edifício religioso. Sentem-se inseguros diante de qualquer tentativa de deflação do cristianismo. Não percebem que esses apetrechos, bebidos com o leite materno no aconchego do lar católico, em vez de mostrar o esplendor da fé, ofuscam-na. Quanto mais penduricalhos a fé adquire, quanto mais afeita a questões exteriores e menos ao evangelho da cruz, mais ela se distancia de seu núcleo duro, mais vazia fica. Essas pessoas não distinguem fé, religião $e$ religiosidade, como ensinava insistentemente o teólogo João Batista Libanio. Ainda ecoa nos ouvidos de seus ex-alunos a voz do professor jesuíta: “[...] Tomemos o exemplo de Jesus na cruz: religião nenhuma, religiosidade zero, fé máxima.” (Informação verbal)5. Para quem não percebe a diferença entre os três conceitos, qualquer crítica ao excesso de religiosidade é recebida como ameaça à verdadeira religião que põe a fé em risco.

Acontece, porém, que, para bem da fé cristã, é preciso, como afirmou Mário Grech (2018), passar “[...] de uma religião de rituais vazios para uma religião que nos abre para o mistério." (GRECH, 2018). Ou, num trocadilho, podemos dizer que é preciso passar do esvaziamento da fé - por excessos de rituais e de dogmatismos -, para a fé do autoesvaziamento, na qual dogmas, preceitos morais e ritos são o modo de verbalizar a fé, mas não a sua garantia. A centralidade da fé se encontra na kénosis de Jesus (Fl 2, 7). O Verbo feito carne (Jo 1, 14), na condição de servo, entregou-se para o bem do mundo. No madeiro do Calvário, ficou visível a importância da fé livre dos escombros de seus excessos, para se chegar à autêntica fé cristã. A vida de Jesus esvaziada de qualquer privilégio é oferta que agrada ao Pai.

Não são poucos os teólogos que fazem coro à atual necessidade de se voltar à fé do auto-esvaziamento, deixando virar quimera de práticas devocionais e construções conceituais que comprometem a experiência do mistério central da fé: a páscoa. Exemplo clássico é a obra Outro cristianismo é possível, do jesuíta belga Roger Lenaers. O apego a formulações dogmáticas plenamente aceitas em outra época, mas postas em xeque hoje graças ao avanço da pesquisa teológica, só faz inflar a fé cristã e esvaziá-la de sentido. Tratase de um reducionismo doutrinal fortemente pernicioso e que ameaça a autêntica vida cristã. Para Carrara (2012), “[...] quando a fé se reduz a um esqueleto conceitual, deixa a impressão de ser apenas mera construção ideológica que não chega a irradiar o mistério e o sabor da

\footnotetext{
5 Trata-se de uma citação repetida insistentemente em sala de aula e registrada na memória de seus ex-alunos e alunas. Desconhecemos se foi registrada por escrito em alguma de suas obras.
} 
transcendência.” (CARRARA, 2012, p. 67). Ao contrário, é na abertura para a novidade do Espírito que se encontra a pérola preciosa da fé cristã. No livro bíblico atribuído a Mateus, o autor (utilizando-se de parábolas), compara o Reino dos céus a um homem que achou uma pérola preciosa (Mt 13, 45-46). Tendo-a encontrado, não se apega mais a nenhum bem; experimenta o esvaziamento de tudo que possuía para de fato ficar pleno da riqueza do Reino de Deus. Assim, pode-se afirmar sem medo de equívocos que, "[...] no vazio de ideias sobre Deus, redescobre-se o Deus verdadeiro como o sentido último da própria existência." (CARRARA, 2012, p. 66).

Para se chegar à fé do auto-esvaziamento, o único caminho é a kénosis. Paulo orientava os filipenses para que tivessem os mesmos sentimentos e pensamentos de Cristo (Fl 2, 5). Com essa exortação, o Apóstolo pretendia evitar que os cristãos de Filipos esfriassem seu fervor inicial por Cristo. Tal risco era real; a fé se via ameaçada por um cristianismo repleto de rituais e leis de pureza, a exemplo dos cristãos judaizantes, ou por muitos privilégios e convenções sociais que os filipenses possuíam antes de aderirem à fé no Ressuscitado. Como esses costumes supervalorizados na cidade de Filipos, uma das grandes metrópoles romanas, Paulo na sua Carta chamava a atenção de seus destinatários para um cristianismo puro e simples, cuja base é o despojamento e não o excesso de ritos religiosos elevados à categoria de fé cristã.

\section{A CARTA6: situação de Paulo e objetivo}

A Epístola aos Filipenses foi escrita com o intuito de chamar os leitores à fé genuína, que se torna concreta no seguimento de Jesus, cuja vida esvaziada de todo privilégio se tornou paradigma da vida cristã. Na linguagem de Paulo, o objetivo é que os destinatários produzam os frutos da justiça para a glória de Deus (Fl 1, 9-11). A expressão significa o resultado do ajustamento a Deus Pai, por meio de Cristo, na ação do Espírito. Como uma roupa feita sob medida se ajusta ao corpo de seu manequim, assim aquele que é justo se ajusta a Deus: vive em comunhão com o Senhor e suas obras ou frutos mostram isso. É como uma árvore plantada junto à água corrente: dá fruto no tempo devido e suas folhas não murcham (Sl 1, 3).

A Carta aos Filipenses localiza Paulo na prisão ( $\mathrm{Fl}$ 1, 7-17) e em risco de morte iminente ( $\mathrm{Fl} 1,21-24)$. O próprio Paulo em $2 \mathrm{Cor}(11,23)$ afirma que foi preso muitas vezes.

\footnotetext{
${ }^{6}$ Consideraremos o texto de Filipenses tal como chegou até nós, ou seja, usaremos o critério da canonicidade sem levar em conta as hipóteses sobre o processo redacional da Epístola (HAWTHORNE, 2008, p. 559).
} 
São pelo menos quatro as hipóteses acerca do local da prisão de Paulo por ocasião da escrita da Carta: Roma, Éfeso, Corinto e Cesaréia (HAWTHORNE, 2008, p. 259-561). A hipótese não coincide exatamente com o que Lucas, o autor dos Atos dos Apóstolos, descreve sobre as prisões de Paulo: Filipos (At 16, 23-40), Cesaréia (At 21, 26-32) e Roma (At 28, 16-31). Apesar de saber que o livro dos Atos dos Apóstolos não é uma crônica dos feitos de Paulo, mas uma construção literária cujo objetivo é mostrar a difusão da boa nova, essa informação não pode ser desprezada. Assim, pairam dúvidas sobre a prisão de Paulo e, consequentemente, sobre a data exata da Carta, enquanto é consenso que a Epístola foi escrita em tempos de cativeiro.

Mas que tipo de prisão Paulo experimentava enquanto escrevia a Carta aos Filipenses? Como cidadão romano (At 22, 25-29), o Apóstolo tinha direito a um tipo de privilégio, um modelo de prisão chamada custodia libera ou liberdade vigiada. Enquanto aos que não portavam tal cidadania cabia a custódia pública ou a detenção penal, o cidadão romano, no entanto, conservava o direito a algumas escolhas como, por exemplo, a residência na qual ficaria em prisão domiciliar, juntamente com um soldado que o vigiava e acompanhava continuamente.

A Carta não esclarece como as notícias sobre a prisão de Paulo chegaram aos cristãos de Filipos, mas afirma que estes - preocupados com o Apóstolo dos gentios - enviaram-lhe uma doação através de Epafrodito ( $\mathrm{Fl} \mathrm{2,} \mathrm{25;} \mathrm{4,} \mathrm{18).} \mathrm{Paulo} \mathrm{manifesta} \mathrm{na} \mathrm{Carta} \mathrm{sua} \mathrm{gratidão}$ pelo cuidado recebido e escreve-lhes no intuito de fortalecê-los na fé. Temendo que os novos convertidos fossem ofuscados pelas glórias apregoadas pelos judaizantes e se afastassem da fé cristã (HAWTHORNE, 2008, p. 561), Paulo fala sobre a kénosis de Cristo e convida seus leitores a seguirem as trilhas do esvaziamento de si como ele próprio procurava fazer.

\section{O FIO CONDUTOR DA CARTA: a kénosis 7}

O Hino Cristológico de Filipenses (2, 6-11) é mais conhecido como hino da kénosis, referência advinda do termo grego kenós, que significa vazio, derivado do verbo kenóo encontrado em Filipenses $(2,7)$ e que tem o sentido de privar-se de poder ou abdicar do que possui (BIBLE HUB, 2020). A expressão caracteriza toda a vida de Jesus, o Filho de Deus, como alguém que não se apegou à sua condição divina e, ao entrar na história humana, assumiu as limitações da mesma. Ele, o Filho de Deus, sujeitou-se às vicissitudes da história,

\footnotetext{
7 O substantivo kénosis, aqui entendido como esvaziamento, não aparece no Novo Testamento. Em Filipenses $(2,7)$, encontra-se o verbo kénoo, no aoristo do indicativo (GNILKA, 1972, p. 211).
} 
tornando-se susceptível ao egoísmo e à violência humana, que fizeram com que sua vida terminasse na cruz (ANDRADE; MIGUEL, 2009, p. 683).

É consenso entre os estudiosos da Escritura que o hino da kénosis não é de autoria paulina $^{8}$. A tese de autoria paulina é muito pouco aceita. Provavelmente o texto é oriundo da liturgia eucarística (SEGANFREDO, 2009, p. 127), o que significa que a teologia kenótica de Filipenses está em consonância com a celebração do mistério pascal, que é o centro em torno do qual a fé cristã gravita. Paulo propõe aos filipenses que façam a experiência do esvaziamento, resgatando a profundidade da mística cristã, que não se deixa desviar pelos adereços da religião. Ao usar o hino cristológico como pressuposto para exortar os filipenses ao esvaziamento, Paulo faz da teologia da kénosis o fundamento da vida de fé e revela que o esvaziamento é a marca identitária da fé em Cristo.

\subsection{A kénosis de Cristo}

Para von Balthasar (1981), a kénosis é o ser mesmo de Deus e o rebaixamento divino pode ser dito em três modalidades: a) Kénosis intratrinitária, em que cada pessoa da Trindade se recolhe em cooperação com as outras; b) Kénosis cosmogônica, em que o DeusCriador se recolhe, se autoesvazia ou se autorrebaixa para criar o mundo; c) Kénosis teantrópica, em que Jesus - de condição divina - se rebaixa assumindo a condição humana e se faz o servo de todos. Em artigo sobre as exigências do reino e a kénosis, Sanches e Danilas (2014, p. 239) também trabalham essas três modalidades divinas. Nessa linha teológica, encontra-se também Ribeiro. Para ela, "[...] Deus é a onipotente impotência quenótica do Amor.” (RIBEIRO, 2004, p. 33). É sobre o terceiro tipo de kénosis, o esvaziamento e rebaixamento de Cristo, que a Carta aos Filipenses se empenha em aprofundar, conforme indica $\mathrm{Fl}$ (2, 6-11).

O movimento abaixamento-exaltação é um elemento estrutural básico de toda a Epístola e está em sintonia com outros textos da Escritura, inclusive do Antigo Testamento. Dentre as referências veterotestamentárias, destacam-se a literatura sapiencial, que exalta a obediência do justo (SEGANFREDO, 2009, p. 132), o Servo Sofredor de Isaías, que experimentou o aniquilamento, e o relato do primeiro humano, que se arrogou o direito de ser como Deus (MALZONI, 2020, p. 158).

\footnotetext{
8 Para Barbaglio (1991), “[...] que o hino seja pré-paulino testemunha-o com certeza a presença de um vocabulário não usado pelo apóstolo e, sobretudo, a presença de temas teológicos que não se encontram em outros lugares do epistolário, ao passo que estão ausentes perspectivas tipicamente paulinas. Em particular, o hino é dominado pela antítese cristológica abaixamento-elevação, quando o apóstolo privilegia o binômio morte-ressurreição." (BARBAGLIO, 1991, p. 377).
} 
Com o Servo Sofredor de Isaías (53), o hino de Filipenses tem uma série de palavras em comum, tais como humilhou-se, tornou-se obediente e foi exaltado por Deus (SEGANFREDO, 2009). Esse vocabulário, no entanto, não o torna dependente de Isaías, pois "[...] a obediência do Servo de Javé não é exatamente a mesma de Cristo." (SEGANFREDO, 2009, p. 133). Se a primeira está na esfera da perseguição ao justo, a segunda encontra-se no âmbito do reconhecimento da condição humana na sua mais pura imanência. A obediência de Cristo não arrefeceu nem mesmo diante da experiência humana mais ignominiosa e humilhante, a morte na cruz (BARBAGLIO, 1991, p. 379).

O texto tem também possibilidade de ser lido na perspectiva de uma cristologia adâmica. O Homem de Nazaré, ao contrário de Adão, o primeiro humano cuja queda deveuse ao desejo de ser como Deus, esvaziou-se de sua condição divina e se fez o último de todos. O vocabulário paulino não é exatamente o mesmo do Gênesis, mas sabe-se que a teologia adâmica é uma constante nas cartas do Apóstolo. Essa leitura analítica também é realizada por Dunn (2003) e outros comentadores como Barbaglio (1991), Casalegno (2001) e Hawthorne, Martin e Reid (2008), como foi mostrado magistralmente no estudo realizado por Malzoni (2020, p. 155-159).

Textos do Novo Testamento mostram Jesus desprezando os excessos da religião e focando sua pregação na interioridade da fé. Ele critica os rituais de pureza (Mc 7, 1-23), expulsa os vendilhões do Templo (Jo 2, 13-22), relativiza o templo e o culto (Jo 4, 19-26), estabelece novas formas de entrar em comunhão com Deus que não se baseiam na religiosidade judaica de seu tempo. Especial sintonia do texto paulino pode ser percebida com o relato do lava-pés, presente em João (13, 3-17), que indica uma transfiguração ou exaltação às avessas (HAWTHORNE, 2008, p. 562). De conviva que ocupa a mesa, Jesus se faz o servo de todos e lava os pés dos seus amigos. Tira o manto e coloca a toalha ou o avental, símbolo do serviço e do rebaixamento a que estaria sujeito em breve no madeiro da maldição. Tendo sinalizado profeticamente que o esvaziamento é uma marca da fé cristã, Jesus propôs em seguida que seus discípulos fizessem o mesmo (Jo 13, 14). No último momento com os seus seguidores, não lhes deu orientações doutrinais, nem ensinou ritos e piedades que se tornassem o distintivo da fé. Ao contrário, desvestiu-se de toda compreensão teológica acerca de Deus e mostrou aos seus discípulos que a fé cristã tem como requisito o esvaziamento ou rebaixamento, a kénosis.

Sua transcendência absoluta, o caráter insondável de seu mistério manifesta-se, mais além de qualquer concepção e imaginação humanas, em sua capacidade de tornar-se pequeno, pobre, de pôr-se ao nosso alcance e de manifestar-se em todo o seu esplendor no mesmo 
momento em que a morte parece tê-lo vencido definitivamente. (BIGAOUETTE, 2014, p. 15).

No hino cristológico de Fl (2, 6-11), assim como no lava-pés, nota-se que Cristo é o autor do rebaixamento. A iniciativa de esvaziar-se é dele. Ele não se apegou à sua forma divina. Ao contrário, optou pelo tipo de vida de todos os homens, efêmeros e mortais (BARBAGLIO, 1991, p. 378). Daí a importância do verbo considerar (hegéomai)99, que se encontra na forma negativa, no aoristo. Cristo não considerou sua forma (ou condição) divina; não se apegou a ela. Esvaziou-se e humilhou-se, o que significa que ele abriu mão de algo importante. Cristo despojou-se de si, rebaixou-se mais ainda se tornando o servo dos servos, terminando sua vida na exposição humilhante de seu corpo no madeiro. "A crucificação, a forma de execução reservada para escravos e pessoas que tinham perdido todos os direitos civis, assinalava o extremo da humilhação humana.” (BYRNE, 2011, p. 448).

Sua atitude de esvaziamento não ficará sem ecos no coração do Pai, que será o responsável por sua elevação. Deus mesmo se digna a exaltá-lo diante de sua atitude kenótica. Como escreve Barbaglio (1991), “[...] a história de Jesus tem, pois, dois tempos nitidamente distintos: no primeiro, Ele é o protagonista ativo da decisão operativa de humilhar-se; no segundo, ao invés, é beneficiário da ação exaltadora de Deus." (BARBAGLIO, 1991, p. 378). Ou, nos dizeres de Byrne:

[...] o ato de abnegação de Cristo é correspondido pela resposta ativa de Deus. Sua obediência é "recompensada", não no sentido de ter forçado Deus, mas de que Deus, em sua fidelidade, agiu para vindicar, "justificar" aquele que havia se colocado totalmente à disposição divina. (BYRNE, 2011, p. 448).

Para Seganfredo (2009, p. 136), na exaltação de Cristo, nota-se que o esvaziamento é a via por excelência de acesso ao Pai. Assim, se de fato alguém quer fazer comunhão com o Deus de Jesus Cristo, não resta outro caminho senão a kénosis. A atitude kenótica de Jesus é dada como exemplar para o agir dos seus seguidores e indica a necessária kénosis da religião cristã. Ou seja, “[...] o modo concreto como Jesus viveu é a fonte e o critério para toda teologia que tenha a pretensão de ser realmente cristã.” (ANDRADE; MIGUEL, 2009, p. 683).

9 Etimologicamente, hegéomai significa “[...] conduzir, seguir na frente, guiar.” (BRANDÃO, 2007, p. 5). 


\subsection{A kénosis de Paulo}

Desde a saudação inicial, Paulo se apresenta como servo (Fl 1, 1) e faz alusão às circunstâncias em que se encontrava por ocasião da Carta (Fl 1, 12-16). Admite que tenha desfrutado de privilégios, dos quais, alegre e livremente, abdicou, considerando-os como lixo por causa de Cristo ( $\mathrm{Fl}$ 3, 7-9). Mostra-se convicto que Deus transformará seu pobre corpo esvaziado de glórias em corpo glorioso, pois Deus tem o poder de sujeitar a si todas as coisas $(\mathrm{Fl} 3,21)$.

Paulo toma como exemplo sua própria vida e suas cadeias para exemplificar a kénosis do discípulo de Cristo. Utiliza o termo grego fronein (fixar a mente em, ter uma atitude de), para convencer os filipenses acerca da vida de humildade e abnegação a que devem estar submetidos ( $\mathrm{Fl} 1,7)$ e para convidar seus leitores a viver do mesmo modo ( $\mathrm{Fl} 3,15)$. Mais à frente, usa a mesma palavra para indicar os interesses egoístas a que os inimigos de Cristo estavam apegados $(\mathrm{Fl} 3,19)$ e, finalmente, a expressão aparece para admoestar os filipenses à solicitude uns com os outros $(\mathrm{Fl} 4,10)$.

Para Paulo, a vida verdadeiramente cristã só é possível no esvaziamento de si mesmo, quando se assume voluntariamente o papel de servo. Por isso, os cristãos da cidade de Filipos deveriam estar dispostos a ter o sangue derramado em libação, no serviço humilde aos irmãos, assim como Paulo (Fl 2, 17); deveriam manter suas energias fixas em valores bem distintos dos que são contrários à cruz de Cristo $(\mathrm{Fl} 3,18-19)$.

A experiência da kénosis de Cristo fez com que o Apóstolo se enveredasse pelo caminho da entrega sem limites, mantendo-o lúcido nas cadeias que suportava. Estando em prisão domiciliar, aguardava o veredito final de sua sentença e sabia que a possibilidade da morte o rondava ( $\mathrm{Fl}$ 1, 12-16). Na sua impotência de fazer mais pela evangelização, Paulo entendia que o evangelho por ele anunciado estava ameaçado por pregadores que só buscavam interesses próprios ( $\mathrm{Fl}$ 1, 15-17; 2, 20-21; 3, 18-19).

Apesar das circunstâncias adversas nas quais a Carta foi escrita, ela não carrega nenhuma tristeza ou melancolia. Pelo contrário, mostra-se um apóstolo cheio de alegria e regozijo ( $\mathrm{Fl}$ 1, 4-25; 2, 2-29; 3, 1; 4, 1-10). Sua fé, fundamentada na experiência pessoal com Deus num passado remoto, alimenta-se também de uma esperança viva. Ela se mostra baseada no próprio ressuscitado, com quem ele se encontrou no caminho de Damasco (At 9, 1-22). Dessa experiência veio todo o conhecimento que transformou sua vida, de modo que o Apóstolo relativizou todas as coisas terrenas, até as mais altamente estimadas, considerando-as lixo ou esterco ( $\mathrm{Fl} 1,19-26 ; 3,4-21)$. 
Mesmo em meio a circunstâncias terríveis, Paulo se alegra, pois as adversidades lhe deram a oportunidade de proclamar o Cristo ( $\mathrm{Fl}$ 1, 12-14). Essa atitude de despojamento, de intenso esvaziamento, aparece no início da Epístola na autodesignação de Paulo: servo (grego: doûlos). Bem diferente de outras Cartas em que Paulo se apresenta como apóstolo de Cristo ( $\mathrm{Rm} \mathrm{1,} 1$; $\mathrm{Cor} 1,1 ; \mathrm{Gl} 1,1 ; \mathrm{Ef} 1,1 ; \mathrm{Cl} 1,1)$, nesta apenas se denomina servo do Cristo Jesus, junto como seu colaborador Timóteo.

Em vez de se tornar um impedimento para a evangelização, a prisão de Paulo proporcionou que sua fidelidade provada a Cristo se tornasse conhecida. Tornou-se motivo de encorajamento para muitos irmãos que pregavam destemidamente o evangelho. Por isso Paulo está seguro de que qualquer que seja a decisão do tribunal acerca de seu destino, o nome de Jesus será glorificado por meio dele. Quer seja libertado da prisão, quer tenha sua morte decretada, seu testemunho de esvaziamento de si mostrará a verdadeira natureza da fé cristã. Por causa de Cristo, tudo o que apreciava como valioso foi considerado lixo. O Apóstolo afirma que abriu mão de tudo, despojou-se de todas as coisas importantes de sua vida pregressa, para ganhar a todos para Cristo. Aprendera a viver na fidelidade a Jesus em qualquer circunstância; enfrentava com destemor tanto a tristeza quanto a perseguição. Mas sabia que, apesar de todo esvaziamento, ainda não era perfeito; corria sem desanimar para alcançar a Cristo, que o alcançara primeiro $(\mathrm{Fl} 3,12)$. Paulo corria em direção à perfeição de Cristo, exercitando-se cada dia num contínuo processo de renúncia e esvaziamento.

Mesmo em meio ao perigo, o Apóstolo segue o caminho do serviço, espelhado na vida de Cristo. A vida kenótica de Jesus dá sentido à sua própria vida; esforça-se para viver em comunhão com o sofrimento do Senhor e com a morte dele ( $\mathrm{Fl} 3,10)$. Por isso podia apontar para si mesmo e dizer, sem traço de vaidade, “[...] sejam meus imitadores como eu sou de Cristo.” (Fl 3, 17).

Paulo põe de lado todos os direitos e privilégios pessoais, para numa atitude de esvaziamento de si, empenhar-se nas necessidades e interesses dos outros. Esse é o coração da Carta. Cristo esvaziou-se de si. No seu seguimento, Paulo se esvazia para melhor servir a exemplo do Cristo. Os filipenses, como o Apóstolo, são chamados pela vocação cristã a assumir essa atitude kenótica, a exemplo de Paulo.

\subsection{Os judaizantes: uma kénosis às avessas}

Se a kénosis de Paulo está garantida, o mesmo não pode ser dito dos judaizantes. Aqueles que anunciavam o evangelho por inveja ou por rivalidade fazem o caminho 
contrário da kénosis, pois buscam reconhecimento e glória. Consideravam a circuncisão da carne e a observância da Lei como mais importante que a cruz de Cristo. Entendiam a salvação como fruto do esforço humano e não como obra redentora de Deus através de seu Filho. Apegavam-se a tudo que Paulo desprezara; tudo que era lixo para ele ainda era coroa de glória para seus opositores. Usurparam o título de missionários, mas não assimilaram a verdadeira radicalidade do discipulado de Cristo. E, para tristeza do Apóstolo, havia quem lhes dava ouvido; entre os filipenses, alguns ainda se sentiam inseguros acerca da identidade cristã, e isso gerava divisões que comprometiam a vida da comunidade.

Por causa disso, Paulo adverte seus destinatários a serem firmes num só espírito e a lutarem juntos como uma só alma por causa do Evangelho. A insistência nessa unidade aponta para uma comunidade com problemas internos, não tão coesa quanto se esperava: “[...] haja entre vós o mesmo sentir e pensar de Cristo Jesus.” (Fl 2, 5). A expressão en Christo, que aparece no grego, é a base da kénosis que Paulo anuncia e vive. Alicerçados no esvaziamento de Cristo, os cristãos são chamados à mesma atitude de humildade e abnegação de si em favor dos outros. A kénosis de Cristo "[...] corta pela raiz qualquer motivo de orgulho humano e veta toda possibilidade de vaidade por parte dos fiéis." (BARBAGLIO, 1991, p. 380). Não é possível seguir a Jesus e garantir glórias e honrarias ao mesmo tempo. “[...] Se dela [da vida de Cristo] são participantes, é inconcebível que se deixem guiar por impulsos de orgulhosa ostentação de si mesmos." (BARBAGLIO, 1991, p. 380). Para quem é discípulo de Jesus, a vida gravita em torno do esvaziamento e da entrega de si e não em torno de seguranças religiosas.

\subsection{A kénosis como pré-requisito para a vida cristã}

Se Cristo, sendo de condição divina, renunciou a todo privilégio e, como o menor de todos, assumiu a existência humana morrendo na cruz, não parece possível outro desfecho para o autêntico seguir do Nazareno. Em conseguinte, Deus o exaltou acima de tudo e de todos, fazendo reconhecida sua soberania sobre todas as realidades. Paulo segue o exemplo de Cristo que se esvaziou de si. Os filipenses devem seguir o exemplo de Paulo, ou seja, devem ter os mesmos sentimentos de Cristo ( $\mathrm{Fl} 2,5)$, pois foi-lhes dada a graça de sofrer com Cristo como o Apóstolo que lhes escreve.

Não é incomum no Corpus Paulinum, aparecerem advertências aos leitores para que se comportem como assembleias cristãs, convocadas pelo Senhor (Ef 4, 1; Cl 1, 10; 1Ts 2, 12). Na carta aos filipenses $(1,27)$, o Apóstolo sai do vocabulário habitual e usa o termo técnico 
politeuomai, ${ }^{10}$ para convidá-los a desempenharem sua obrigação como cidadãos. Os filipenses eram orgulhosos de seu status de cidadãos romanos e poderiam entender a expressão como uma referência às suas obrigações para com a cidade (HAWTHORNE, 2008, p. 557). Contudo, Paulo não os convocava a uma cidadania exemplar ao modo romano, mas a cumprirem seus deveres para com a comunidade cristã. Apesar de não explicar imediatamente o que isso significa, faz entrever uma vida de esvaziamento e entrega ainda que o preço a pagar fosse alto: a união ao sofrimento de Cristo (Fl 1, 29-30). O chamado à cidadania própria do evangelho aparece em Filipenses (2, 1-4), quando Paulo os convida a renovarem a unidade no cuidado uns com os outros.

A unidade da comunidade de Filipos está ameaçada, pois o egoísmo e a arrogância não coadunam com a vida cristã $(\mathrm{Fl} 2,3)$. A dissensão interna está tirando de cena o amor, a comunhão e o companheirismo ( $\mathrm{Fl} 2,14 ; 3,18-19 ; 4,2)$. A solução proposta por Paulo é o amor, prioridade máxima dos crentes, atitude de vida que coloca o bem-estar e os interesses dos outros acima dos interesses próprios ( $\mathrm{Fl} \mathrm{2,3-4).} \mathrm{Paulo} \mathrm{incentiva} \mathrm{os} \mathrm{filipenses} \mathrm{à}$ humildade, que é inerente à fé cristã. Assim, como cidadãos dos céus, cumpririam suas obrigações para com a comunidade de fé, e a própria comunidade de fé se edificaria sobre bases sólidas ( $\mathrm{Fl} \mathrm{3,17-20).} \mathrm{O} \mathrm{hino} \mathrm{cristológico,} \mathrm{utilizado} \mathrm{por} \mathrm{Paulo} \mathrm{no} \mathrm{capítulo} \mathrm{2,} \mathrm{torna-se} \mathrm{o}$ fundamento da kénosis que se impõe como pré-requisito para a vida cristã.

Nota-se, pois, que a dobradinha abaixamento-exaltação ou esvaziamentoplenificação é o elemento estrutural básico da Epístola aos Filipenses. Paulo, o servo de Cristo $(\mathrm{Fl} \mathrm{1,1)}$ testemunha que desfrutou de muitos privilégios dos quais livremente abdicou por causa da fé no Filho de Deus (Fl 3, 7-9). Nessa kénosis, espera que Deus - que glorificou o Cristo - aceite a oferta de sua vida e transforme o seu pobre corpo mortal em corpo glorioso, pois Deus tem o poder de sujeitar a si todas as coisas ( $\mathrm{Fl} 3,21)$. Independentemente do que acontecerá a si mesmo, Paulo está seguro de que fez o processo que deveria fazer. Não se apega a mais nada, pois já entendeu que “[...] viver é Cristo e morrer é lucro.” (Fl 1, 21).

Paulo mostra que o chamado à vida cristã se dá no esvaziamento de si mesmo, que o cristão deve assumir o papel de servo, de último de todos. E que, ainda que seja preciso derramar o sangue no serviço aos outros ( $\mathrm{Fl}$ 2, 17), terá valido a pena. Resta aos filipenses, como admiradores de Paulo, fazerem o mesmo, sem se deixarem influenciar pelos judaizantes.

${ }^{10}$ Termo de origem grega que significa etimologicamente viver como cidadão (BIBLE HUB, 2020). 


\section{CONSIDERAÇÕES FINAIS: na contramão da glória}

Inspirados na Carta aos Filipenses, não seria demais afirmar como James Alison que “[...] o protagonismo divino é forte, fortíssimo, ao passo que a presença divina é debilíssima. E o mais curioso é que a debilidade da presença é precisamente devido à força do protagonismo." (ALISON, 2008, p. 42, tradução nossa). ${ }^{11}$ Exatamente na fé do autoesvaziamento residem sua riqueza e sua glória, e não nos excessos religiosos.

Na sobriedade da cruz, encontra-se a glória da ressurreição, pois é justamente pelo fato de Jesus ter se entregado sem reservas até o aniquilamento total que ele teve o veredito divino a seu favor: a ressureição (SEGANFREDO, 2009, p. 130).

Assim, se queremos ser de fato identificados como discípulos de Jesus, cuja práxis se firmou no esvaziamento por amor e não na inflação de certezas dogmáticas ou práticas devocionais, devemos seguir o caminho da kénosis indicada por Paulo aos filipenses. Kénosis pessoal e kénosis da religião. Afinal, a fé cristã é a religião do amor desmedido de Cristo, visibilizado no seu esvaziamento. E o caminho da fé pensado a partir da pequena via do amor funda-se mais “[...] na nudez, na dúvida e na desolação [...]” (CARRARA, 2012, p. 65), que no ufanismo, na verdade universal e na vitória.

\section{REFERÊNCIAS}

1 CORÍNTIOS. In: A BÍBLIA DE JERUSALÉM: nova edição. São Paulo: Paulinas, 1989.

1 TESSALONICENSES. In: A BÍBLIA DE JERUSALÉM: nova edição. São Paulo: Paulinas, 1989.

2 CORÍNTIOS. In: A BÍBLIA DE JERUSALÉM: nova edição. São Paulo: Paulinas, 1989.

ALINSON, J. Los cambios de tono en la voz de Dios: entre el deseo divino y la marea humana. In: MENDOZA-ÁLVAREZ, C. (org.). ¿Cristianismo posmoderno o postsecular? Por una interpretación teológica de la modernidad tardía. México: Universidad Iberoamericana, 2008. p. 39-53.

ANDRADE, A. L. P.; MIGUEL, I. S. Tende em vós os mesmos sentimentos de Cristo Jesus (Fl 2, 5). Convergência, Rio de Janeiro, v. 44, n. 426, p. 676-692, 2009. Disponível em: http://geif.com.br/wp-content/uploads/2014/o1/TENDE-EM-V\%C3\%93S-OS-MESMOSSENTIMENTOS-DE-CRISTO.pdf. Acesso em: 27 set. 2021.

${ }_{11}$ "[...] el protagonismo divino es fortísimo, fuerte a mas non poder, pero la presencia divina es debilísima. $Y$ lo más curioso es que la misma debilidad de presencia es precisamente debida a la fuerza del protagonismo". 
ATOS DOS APÓSTOLOS. In: A BÍBLIA DE JERUSALÉM: nova edição. São Paulo: Paulinas, 1989.

BALThASAR, H. U. Pâques les Mystère. Paris: Éditions du CERF, 1981.

BARbaglio, G. As Cartas de Paulo II. São Paulo: Loyola, 1991.

BIGAOUETTE, F. O grito de Jesus na cruz e seus ecos na contemporaneidade. Cadernos Teologia Pública, São Leopoldo, v. 11, n. 89, p. 4-18, 2014. Disponível em: http://www.ihu.unisinos.br/159-noticias/entrevistas/530416-o-grito-de-jesus-na-cruzum-chamado-para-a-conversao-radical-do-nosso-juizo-sobre-deus-e-nos-mesmosentrevista-especial-com-francine-bigaouette. Acesso em: 02 mar. 2021.

BRANDÃO, J. L. Diegese em república 392d. Kriterion, Belo Horizonte, v. 48, n. 116, p. 351-366, 2007. Disponível em:

https://www.scielo.br/scielo.php?script=sci_arttext\&pid=So100-512X2007000200005. Acesso em: 10 mar. 2021.

BYRNE, B. A Carta aos Filipenses. In: BROWN, R. E.; FITZMYER, J. A.; MURPH, R. E. (org.). Novo Comentário Bíblico São Jerônimo. São Paulo: Paulus, 2011. p. 441-452.

CARRARA, P. S. Itinerarium mentis in Deum per nihilum. Perspectiva Teológica, Belo Horizonte, v. 44, n. 122, p. 53-68, 2012. Disponível em:

http://www.faje.edu.br/periodicos/index.php/perspectiva/article/view/1591. Acesso em: 02 mar. 2021.

CASALEGNO, A. Paulo: o evangelho do amor fiel a Deus: introdução às cartas e à teologia paulina. São Paulo: Loyola, 2001.

CODINA, V. Prioridade teológico-pastoral da pneumatologia hoje. Perspectiva

Teológica, Belo Horizonte, v. 44, n. 122, p. 69-86, 2012. Disponível em:

http://www.faje.edu.br/periodicos/index.php/perspectiva/article/view/1592/1942. Acesso em: 02 de março de 2021.

COLOSSENSES. In: A BÍBLIA DE JERUSALÉM: nova edição. São Paulo: Paulinas, 1989.

COUTINHO, S. R. CNBB (1968) x CNBB (2018): a 50 anos de distância o que esperar? Revista IHU Online. São Leopoldo, 23 abr. 2018. Disponível em:

http://www.ihu.unisinos.br/78-noticias/578196-cnbb-1968-x-cnbb-2018-a-50-anos-dedistancia-o-que-esperar. Acesso em: 25 abr. 2018.

DUNN, J. A teologia do apóstolo Paulo. São Paulo: Paulus, 2003.

EFÉSIOS. In: A BÍBLIA DE JERUSALÉM: nova edição. São Paulo: Paulinas, 1989.

FERREIRA, V. P. Cristianismo não religioso em Gianni Vattimo. Aparecida: Santuário, 2015.

FILIPENSES. In: A BÍBLIA DE JERUSALÉM: nova edição. São Paulo: Paulinas, 1989. 
FRANCISCO, Papa. Exortação Apostólica Evangelli Gaudium: sobre o anúncio do evangelho no mundo atual. São Paulo: Paulinas, 2015.

GÁLATAS. In: A BÍBLIA DE JERUSALÉM: nova edição. São Paulo: Paulinas, 1989.

GÊNESIS. In: A BÍBLIA DE JERUSALÉM: nova edição. São Paulo: Paulinas, 1989.

GNILKA, J. La lettera ai Filippese. Bresia: Paideia, 1972.

GRECH, M. Um cristianismo sem religião. Revista IHU Online. São Leopoldo, 21 abr. 2018. Disponível em: http://www.ihu.unisinos.br/78-noticias/578027-um-cristianismosem-religiao. Acesso em: 02 mar. 2021.

HAWTHORNE, G. F. Carta aos Filipenses. In: HAWTHORNE, G. F.; MARTIN, R. P.; REID, D. G. (org.). Dicionário de Paulo e suas Cartas. São Paulo: Loyola, 2008. p. 556-564.

HAWTHORNe, G. F.; MARTIN, R. P.; REID, D. G. (org.). Dicionário de Paulo e suas Cartas. São Paulo: Loyola, 2008.

JOÃO. In: A BÍBLIA DE JERUSALÉM: nova edição. São Paulo: Paulinas, 1989.

KENOÓ. In: BIBLE HUB: dicionário bíblico online, 2020. Disponível em:

https://biblehub.com/greek/2758.htm. Acesso em: 30 dez. 2020.

LENAERS, R. Outro cristianismo é possível. São Paulo: Paulus, 2010.

LIBANIO, J. B. Tendências religiosas do mundo contemporâneo. Vida Pastoral, São Paulo, v. 50, n. 266, p. 12-19, 2009. Disponível em:

https://www.vidapastoral.com.br/artigos/ciencias-da-religiao/tendencias-religiosas-domundo-contemporaneo. Acesso em: 02 mar. 2021.

MALZONI, C. V. Em forma de Deus, em forma de escravo: a propósito da tradução de morphé, -és, em Fl 2, 6-7 nas edições da bíblia no Brasil. Perspectiva Teológica, Belo Horizonte, v. 52, n. 1, p. 143-162, 2020. Disponível em:

https://www.faje.edu.br/periodicos/index.php/perspectiva/article/view/4389. Acesso em: 02 mar. 2021.

MATEUS. In: A BÍBLIA DE JERUSALÉM: nova edição. São Paulo: Paulinas, 1989.

MARCOS. In: A BÍBLIA DE JERUSALÉM: nova edição. São Paulo: Paulinas, 1989.

POLITEUOMAI. In: BIBLE HUB: dicionário bíblico online, 2020. Disponível em: https://biblehub.com/greek/4176.htm. Acesso em: 30 dez. 2020.

RIBEIRO, C. S. M. Mysterium Paschale: a quenose de Deus segundo Hans Urs von Balthasar. São Paulo: Loyola, 2004.

ROMANOS. In: A BÍBLIA DE JERUSALÉM: nova edição. São Paulo: Paulinas, 1989.

SALMOS. In: A BÍBLIA DE JERUSALÉM: nova edição. São Paulo: Paulinas, 1989. 
SANCHES, M. A.; DANILAS, S. Relações entre o Deus triúno e o mundo: kenosis e reino. Estudos Teológicos, São Leopoldo, v. 54, n. 2, p. 230-241, 2014. Disponível em: http://periodicos.est.edu.br/index.php/estudos_teologicos/article/view/1194/2247. Acesso em: 02 mar. 2021.

SEGANFREDO, A. C. Filipenses 6,2-11: ponto de partida para chegar ao considerar de Cristo Jesus e de Paulo como proposta para o agir cristão. Espaços, São Paulo, v. 17, n. 2, p. 125-139, 2009. Disponível em:

https://espacos.ittesp.com.br/index.php/espacos/article/view/314/221. Acesso em: 06 mar. 2021.

URQUHART, G. A armada do papa: os segredos e o poder das novas seitas da Igreja Católica. Rio de Janeiro: Record, 2002.

Recebido em: 04jan. 2021 Aprovado em: o9jul. 2021 